\title{
The Relationship between Irrational Beliefs, Resilience, Psychological Needs, Cyberbullying and Cyber Victimization
}

\author{
Yunus Sabancı ${ }^{1}$, Ali Çekiç ${ }^{2, *}$ \\ ${ }^{1}$ Ministry of Education, Malatya, Turkey \\ ${ }^{2}$ Department of Psychological Counseling, Faculty of Education, Gaziantep University, Turkey
}

Copyright $\bigcirc 2019$ by authors, all rights reserved. Authors agree that this article remains permanently open access under the terms of the Creative Commons Attribution License 4.0 International License

\begin{abstract}
The aim of this research is to reveal whether resilience, irrational beliefs and psychological needs are significant predictors of cyberbullying and cyber victimization in adolescents. The research sample consisted of 849 students that studied in a high school. Personal Information Form, Revised Cyberbullying Inventory, Irrational Beliefs Scale Adolescent Form, Child and Youth Resilience Scale Brief Form and New Psychological Needs Evaluation Scale were used for data collection. Results showed that, $14.9 \%, 18.6 \%$ and $8.9 \%$ of the students were cyberbullies, cyber victims and cyberbullies/ cyber victims, respectively. According to the results, boys who participated in the study showed that they experienced more cyber bullying $(\overline{\mathrm{X}}=1.28)$ than girls $(\overline{\mathrm{X}}$ $=1.23$ ). Similarly, the mean score of boys in cyber victimization $(\overline{\mathrm{X}}=1.27)$ was higher than females $(\overline{\mathrm{X}}=1.23)$. In terms of parental attitudes, students who are exposed to unrelated parental attitudes are more likely to be cyber bullies. On the other hand, students exposed to oppressive parental attitudes experience more cyber victimization. It was also found that irrational beliefs, resilience and psychological needs (success, dominance, autonomy and need for relationship) significantly predicted cyber bullying and victimization. The findings will provide a better understanding of cyberbullying behaviors of adolescents and other variables such as psychological needs and beliefs, which are a significant consequence of parental behavior and parent child interaction.
\end{abstract}

Keywords Cyberbullying, Cyber Victimization, Irrational Beliefs, Resilience, Psychological Needs

\section{Introduction}

Technology provides many opportunities especially for young people to talk to many different people that are outside their social circle, communicate with their family and friends with greater ease and frequency, and to establish social bonds that might be difficult to create in person [1]. The use of these new technologies in the field of education has increased social interaction among students and enabled cooperative learning. However, common use of electronic communication tools has also brought some problems. The most striking problem is the severely increased cyberbullying behaviors at schools [2]. Cyberbullying is generally defined as an intentional, aggressive and repetitive action performed by a person or a group using a computer, mobile phone or other information tools against a victim that cannot defend himself/herself easily $[3,4]$.

Gossiping and rumormongering, taking photographs and spreading them without permission of that person or targeting a certain group with racist discourse have been the common bullying behaviors among adolescents. However, today's bullies continue to display such behaviors through various technological instruments such as e-mail, list servers, cell phones and websites. This new and different style of bullying can provide bullies the ability to hide themselves and give them the opportunity to continue their abuses in the victims' own homes. It can even become a worldwide issue rather than just an in-class or in-school issue of gossip or rumors [5]. With such various types, cyberbullying has negative consequences on victims ranging from depression, anger, sorrow, anxiety, academic difficulties, family problems, feelings of worthlessness, substance addiction, eating disorders to suicide $[6,7]$. According to studies undertaken on the effects of cyberbullying on adolescents, adolescents are exposed to cyberbullying experience negative effects, such as low self-esteem, loneliness, frustration, mistrust in others, self-destruction, aggressiveness towards friends and family [8], and experience headaches, stomachaches 
and sleep disorders [9], fear, anger, uneasiness, reduction in study time and academic success, sleeping disorders, fear of being alone or going outside and suicidal thoughts [10]. In spite of all these negative side-effects, adolescents still do cyberbullying; due to wanting to take revenge, because of the wrong attitude or behavior that the person is exposed to joking [11,12] or having fun [13].

The aim of this study is to gain a better understanding the cyberbullying behaviors that are performed for various reasons especially among adolescents, which leave several negative traces on victims. In the research, cyberbullying which is increasingly seen as a behavior among adolescents, and cyber victimization, one of its results, are addressed in terms of irrational beliefs, psychological needs and resilience concepts to better understand the issue. For this purpose, our hypothesis claims that both cyberbullying and cyber victimization differ in terms of certain variables such as gender, class level, parents' educational status and attitudes, and time and place of internet usage. It is also presumed that adolescents' irrational beliefs, psychological needs and resilience predict whether they will be cyber bully or victim.

\section{Materials and Methods}

\subsection{Participants and Procedure}

For this study conducted on adolescents, the necessary permissions were obtained from Gaziantep University Educational Sciences Institute and Malatya Provincial Directorate of National Education respectively in line with the Helsinki Declaration. Later, the researcher applied scales to students with the help of psychological counselors working in schools. Applications are made in grades with paper-pencil path. The students were informed about the aim of the research, the ethical principles to be considered in the use of the research data. In addition, it was stated that participation in the research was based on volunteer, and the measurement tools were applied to the volunteer students. The study was performed with a total of 849 students, of which 430 were females $(50.6 \%)$ and 419 were males $(49.4 \%)$, that studied in the $9^{\text {th }}, 10^{\text {th }}, 11^{\text {th }}$ and $12^{\text {th }}$ grades in four public high schools in Malatya, Turkey during the 2015-2016 academic year. The research data was collected in face-to-face interviews after taking the necessary permissions.

The educational status of the participating adolescents' mothers $(89.5 \%)$ and fathers $(76.9 \%)$ were mainly within primary and high school range; $56.9 \%$ of the adolescents used Internet for five hours or more a week; and attitudes of $45.6 \%$ of parents were protective.

\subsection{Measures}

Revised Cyberbullying Inventory (RCBI): The
Cyberbullying Inventory (CBI) was originally developed by Erdur-Baker and Kavşut [14]. Then, Erdur-Baker [15] revised the instrument, and developed the Cyberbullying Inventory-Revised (RCBI). RCBI, contains two parallel forms, each of which consists of 14 questions. Each scale item includes likert type evaluation in the range of 1 to 4 points. The lowest score in each dimension is 14; and the highest one is 56. Higher scores refer to higher levels of cyberbullying and cyber victimization. The inventory had two dimensions including, cyberbullying and cyber victimization. As part of this research, the Cronbach Alpha internal consistency coefficient was found as 0.88 and 0.84 for cyberbullying and cyber victimization, respectively.

Irrational Beliefs Scale Adolescent Form: Developed by Türküm, Balkaya and Karaca [16], the İrrational Beliefs Scale Adolescent Form (IBS-A) consists of 16 items which are anchored on a 5-point Likert scale. The lowest and highest possible scores that can be obtained from the scale are 16 and 80 , respectively. The increase in the scores received from the scale refers to highness of the irrational beliefs scores. The Cronbach Alpha internal consistency value was .70 in its original version while it was measured as 0.62 in this study.

Children and Youth Resilience Scale Brief Form: This form was developed by Liebenberg, Ungarve LeBlanc [17] and adapted to Turkish by Arslan [18], the Child and Youth Resilience Scale Brief Form (CYRS) consists of 12 items and is in the form of a 5 point Likert scale. The lowest and highest possible scores that can be obtained from the scale are 12 and 60 , respectively. The higher the score taken from the scale is, the higher the resilience level is. According to the reliability study, the internal consistency coefficient of CYRS was researched and the Cronbach Alpha coefficient was found as 0.78 .

New Psychological Needs Evaluation Scale: Originally developed by Heckert et al. [19] and adapted to Turkish by Kesici [20], the New Psychological Needs Evaluation Scale (NPNES) consists of 20 items and 4 sub-dimensions. These sub-dimensions are Success, Relationship, Autonomy and Dominance. Each sub-dimensions consist of 5 items which are anchored on a 5-point Likert scale. The total score that can be obtained by an individual from the NPNES is a maximum of 25 and a minimum of 5. Cronbach Alpha value was .80 in Kesici's version [20], while it was found as .66 in the current study.

Personal Information Form: Personal Information Form consists of 7 questions on students' gender, grade, educational status of parents, attitude of parents, duration of Internet use and location of Internet connection. The personal information form was applied to students who volunteered for research together with other measurement tools.

Data Analysis: The SPSS-21 was used in data analysis; t-test (Independent Samples Test), one way variance analysis (One-Way-Anova), multiple linear regression and Tukey multiple comparison test were used for independent 
groups. In comparisons, significance level was considered as $\alpha=0.05$.

\section{Results}

It was found that $9.3 \%$ and $20.7 \%$ of the female and male students were cyberbullies, respectively, and $15.1 \%$ of the females and $22.1 \%$ of the males were cyber victims. The difference between the mean cyberbully scores of females $(\overline{\mathrm{X}}=1.23)$ and males $(\overline{\mathrm{X}}=1.28)$ was considered significant $[\mathrm{t}(847)=-5.070, \mathrm{P}<0.05]$. As such, the difference between the mean cyber victim scores of females $(\overline{\mathrm{X}}=1.23)$ and males $(\bar{X}=1.27)$ was also considered significant $[\mathrm{t}(847)=$ -4.024, $\mathrm{P}<0.05]$. Accordingly, it can be said that male students are both engaged in cyberbullying and experience cyber victimization at a more significant level.

According to the grade levels, the difference between the cyber bullying and victimization scores was significant as well $[\mathrm{F}(3,845)=0.192, \mathrm{P}=0.902 ; \mathrm{F}(3,845)=0.662, \mathrm{P}=$ 0.576 , respectively]. The difference between the cyber bullying and victimization scores was significant according to the educational status of mother $[\mathrm{F}(3,845)=9.003, \mathrm{P}=$ $0.000 ; \quad \mathrm{F}(3,845)=4.729, \quad \mathrm{P}=0.003, \quad$ respectively] . According to the Tukey multiple comparison test, students whose mother's education level is secondary or higher obtained higher score from the RCBI than students whose mothers were primary school graduates. In terms of cyber victimization, the results show that students whose mothers were high school graduates were exposed to cyber victimization at a higher degree as compared to those whose mothers were primary school graduates.

According to the difference between the cyber bully and victim scores based on the educational status of father, the difference seems significant $[\mathrm{F}(3,845)=7.177, \mathrm{P}=0.000]$. According to the Tukey multiple comparison test conducted to identify which groups were the cause of difference, it was seen that students whose fathers were "university graduates" were cyberbullies at a significantly higher level as compared to the students whose fathers graduated from "primary and secondary school". In other words, the higher the educational status of father was, the greater the cyberbullying behaviors increased. The difference between the cyber victimization scores, on the other hand, was insignificant $[\mathrm{F}(3,845)=3.093, \mathrm{P}=0.056]$.

According to the perceived attitude of parents, the difference between the cyber bullying and victimization scores was significant $[\mathrm{F}(4,844)=4.678, \mathrm{P}=0.001]$. As such, difference between the cyber victim scores was significant $[\mathrm{F}(4,844)=5.313, \mathrm{P}=0.000]$. In the Tukey multiple comparison test conducted to determine which groups caused the difference, it was seen that the difference in cyber bully scores resulted from the group that demonstrated oppressive, protective and indifferent parent attitudes and students that were exposed to indifferent parent attitudes were more engaged in cyberbullying as compared to the students with oppressive and protective parents. The difference in the cyber victim scores, on the other hand, resulted from groups with oppressive, protective and inconsistent parent attitudes with students that were exposed to oppressive parent attitudes became cyber victims more frequently as compared to the students that had parents with inconsistent and protective attitudes.

In terms of duration of Internet use, the difference between cyber bully $[\mathrm{F}(4,844)=38.597, \mathrm{P}=0.000]$ and cyber victim scores was also significant $[\mathrm{F}(4,844)=16.922$, $\mathrm{P}=0.000]$. According to the Tukey multiple comparison test, students that used Internet for an average of 16 hours or more a week were observed to be cyber bullies and victims at a higher degree as compared to those that never used Internet or used for 1-5 hours, 6-10 hours and 11-15 hours. In other words, the longer the duration of Internet use is, the more cyber bullying and victimization levels increase. There was no significant difference between cyber bully and victim scores based on the location of Internet connection $[\mathrm{F}(3,845)=1.034, \mathrm{P}=0.377 ; \mathrm{F}(3$, $845)=0.245, \mathrm{P}=0.865]$.

A regression analysis was performed to better understand the cyber bullying and victimization concepts among adolescents and to determine the variables that predict both cyberbullying and cyber victimization (Table 1).

There was a significant relationship between Irrational Beliefs, Resilience and Psychologic Needs variables and cyberbullying scores $\left(\mathrm{R}=0.332, \mathrm{R}^{2}=0.110\right)$. İrational Beliefs, Resilience and Psychologic Needs are seen as significant predictors of cyberbullying $[\mathrm{F}(6-842)=17.398$, $\mathrm{P}<0.05]$. Additionally, irrational beliefs, resilience, success, autonomy and dominance need account for $11 \%$ of the total variance in cyberbullying. According to the standardized regression coefficients $(\boldsymbol{\beta})$, the relative order of importance of the predictive variables on cyberbullying was resilience, need for success, need for autonomy, need for dominance, need for relationship and irrational beliefs. According to the t-test results on the significance of regression coefficients, it is seen that resilience, need for success and autonomy were significant predictors on cyberbullying whereas irrational beliefs and need for relationship and dominance did not have a significant effect on cyberbullying. 
Table 1. The regression analysis results related to predictive levels of irrational beliefs, psychological needs and resilience on cyberbullying.

\begin{tabular}{|c|c|c|c|c|c|}
\hline Variables & B & $\mathbf{S E}$ & $\boldsymbol{\beta}$ & t & $\mathbf{p}$ \\
\hline Constant & 1,429 & 0,51 & & 28,183 &, 000 \\
\hline Irrational Beliefs &, 005 &, 001 &, 003 &, 078 & ,937 \\
\hline Resilience &,- 004 &, 001 &,- 226 & $-6,277$ &, 000 \\
\hline Success &,- 006 &, 002 &,- 152 & $-3,887$ &, 000 \\
\hline Relationship &,- 001 &, 002 &,- 013 &,- 369 & ,712 \\
\hline Autonomy &, 005 &, 001 &, 134 & 3,658 &, 000 \\
\hline Dominance &, 003 &, 001 &, 072 & 1,837 &, 067 \\
\hline $\mathrm{R}=, \mathbf{3 3 2}$ & $R^{2}=, 110$ & \multicolumn{3}{|c|}{$F(6-842)=17,398$} & $p=, 000$ \\
\hline
\end{tabular}

Table 2. The regression analysis results related to predictive levels of irrational beliefs, psychological needs and resilience on cyber victimization.

\begin{tabular}{|c|c|c|c|c|c|}
\hline Variables & B & SE & $\boldsymbol{\beta}$ & $\mathbf{t}$ & $\mathbf{P}$ \\
\hline Constant & 1,383 & 0,044 & & 31,546 &, 000 \\
\hline Irrational Beliefs &, 001 &, 001 &, 072 & 2,079 &, 038 \\
\hline Resilience &,- 005 &, 001 &,- 320 & $-8,946$ &, 000 \\
\hline Success &,- 003 &, 001 &,- 095 & $-2,436$ & ,015 \\
\hline Relationship &, 002 &, 001 &, 044 & 1,309 &, 191 \\
\hline Autonomy &, 003 &, 001 &, 072 & 1,964 &, 050 \\
\hline Dominance &, 002 &, 001 &, 059 & 1,523 &, 128 \\
\hline $\mathrm{R}=, \mathbf{3 5 5}$ & & ,126 & & $F(6-842)=20,191$ & $P=, 000$ \\
\hline
\end{tabular}

There was a significant correlation between irrational beliefs, resilience and psychologic needs variables and cyber victimization scores $\left(\mathrm{R}=0.355, \mathrm{R}^{2}=0.126\right)$. İrational Beliefs, Resilience and Psychologic Needs are seen as significant predictors of cyber victimization $[\mathrm{F}(6-842)=$ 20.191, $\mathrm{P}<0.05]$. Additionally, irrational beliefs, resilience, success, relationship, autonomy and dominance need account for $12.6 \%$ of the total variance in cyber victimization. According to the standardized regression coefficients $(\boldsymbol{\beta})$, the relative order of importance of the predictive variables on cyber victimization was resilience, need for success, irrational beliefs, need for autonomy, need for dominance and need for relationship. According to the t-test results on the significance of regression coefficients, it is seen that resilience, irrational beliefs and need for success and autonomy were significant predictors for cyber victimization whereas need for relationship and dominance did not have a significant effect on cyber victimization (Table 2).

Any comments and suggestions are welcomed so that we can constantly improve this template to satisfy all authors' research needs.

\section{Conclusions}

Research results based on gender show that there was a significant difference between cyber bullying and victimization scores. Males were cyber bullies and victims at a higher degree as compared to females. This result is consistent with the results of many studies [21, 22, 23, 24] in the literature. Both Bayhan [25] and Kelleci [26], in their research on high school students, reported that male students' internet usage times were 2 to 4 times higher than female students. This finding can be interpreted as a poorer parental control of male students' use of technology. In addition, boys are exposed to more beatings by their parents, which results in sudden outbursts of anger [27]. This might lead them to embrace both cyberbullying and cyber victimization more easily, and perceive bullying as a method of problem solving.

In terms of attitudes of parents, students that were exposed to an indifferent attitude demonstrated more cyberbullying behaviors as compared to the students that were exposed to oppressive and protective attitudes. Whereas students that were exposed to oppressive parental attitudes became cyber victims more frequently as compared to the students that were exposed to inconsistent and protective attitudes. According to the literature, there is research showing that parent attitudes constitute an effective variable on cyberbullying and cyber victimization. Smilarly, Baykal [28] in a study that conducted with high school students, revealed that parental attitudes can be a determinant on bullying and victimization. Makri-Botsari and Karagianni [29] suggested that parent attitudes are not a significant predictor of cyber victimization, but they are 
the predictor of cyberbullying.

As a result of the study, it was seen that cyberbullying and cyber victimization increased as the students' duration of Internet use increased. In the literature, there are several studies that support this finding $[28,30,31,32]$. However, Özdemir and Akar [33] stated that there is a correlation between the duration of Internet use and cyberbullying, but there is no such correlation with cyber victimization. Semerci [34] suggested that there is no correlation between the duration of Internet use and cyber bullying and victimization.

It was found that irrational beliefs of adolescents significantly predicted the cyber victimization only. There is no study in literature that researched the correlation between irrational beliefs and cyberbullying. However, Birle and Boşca [35] suggested a positive significant correlation between cyberbullying and irrational beliefs. Fives et al. [36] stated that irrational beliefs predicted physical and indirect aggression in their study conducted with high school students.

Resilience was found to be a significant predictor of both the cyberbullying and cyber victimization as a result of the study. In their study conducted with 444 adolescents, Kabaday and Sarı [37] researched the role of resilience on cyber bullying and victimization, and suggested that resilience significantly predicted cyber bullying and victimization, similar to this study. Hinduja and Patchin [38] stated that resilience was a strong protective factor on cyberbullying in their study conducted with 1204 adolescents. As such, Navarro et al. [39] suggested that resilience had a protective function in terms of results of cyber victimization as a result of their study conducted with 643 adolescents.

As another research result, the need for success and autonomy were found to be significant predictors of cyber bullying and victimization. Dilmaç [40] examined the psychological needs that predicted cyberbullying with 666 university students, and stated that aggressiveness and drawing attention positively predicted cyberbullying; there was a negative correlation between understanding feelings and cyberbullying; persistence and closeness negatively predicted exposure to cyberbullying; and there was a weak but positive correlation between the need for change and exposure to cyberbullying. Eşici [41] stated that there was a negative significant correlation between belonging, power and general basic needs and bullying behaviors whereas the correlation between freedom and bullying was positive significant.

As a consequence, this study showed that boys both performed a higher degree of cyberbullying and experienced more cyber victimization as compared to girls. The duration of Internet use, attitudes of parents and educational status of parents were observed to be effective variables on cyber bullying and victimization. Additionally, it was seen that resilience and need for success and autonomy were significant predictors of cyber bullying and victimization whereas irrational beliefs were significant predictors of cyber victimization only.

\section{Limitations and Future Directions}

During the application of the instrument, it was observed that some students asked about the aim of the study and had specific worries about being evaluated. For instance, students often expressed their worries by asking such questions: "Does this study assess how much of a bully we are?". Although the researcher ensured them that such data would not be used for personal assessments and personal information such as their names and surnames weren't asked for, students might try to show themselves in a different way concerning cyberbullying since the behavior is perceived as an unpleasant and negative. Thus, this is thought to be limitation of the study.

The Cronbach Alpha internal consistency coefficients of the instruments NPNES and IBS-A were under .70. The use of both scales with this sample can be seen as a limitation of the study.

In light of these findings, it is recommended that psychological counsellors, computer teachers or experts in the field should conduct cyberbullying awareness activities for students in rapidly increasing cyber bullying and victimization cases among students. Additionally, it is thought that organization of family education programs at schools aimed at attitudes of parents will be beneficial in the fight against cyberbullying. The creation of a school climate that will increase the success desired of students and meet the need for autonomy will also be important. Performance of activities that will increase the resilience levels of students at schools will especially be useful in reduction of the negative results of cyber victimization. Lastly, application of education programs based on Cognitive Behavioral Therapy for students that are exposed to cyberbullying will be beneficial for the coping skills of adolescents.

\section{Acknowledgements}

First of all, we are very grateful to experts for their appropriate and constructive suggestions to improve this template. We would also like to thank school counseling for help in the data collection process. This work was produced from a master's thesis conducted in the Department of Psychological Counseling and Guidance in the Institute of Educational Sciences at Gaziantep University. We would also like to thank professors for their valuable opinions and suggestions during this process. 


\section{REFERENCES}

[1] David-Ferdon, C., \& Hertz, M. F. Electronic Media and Youth Violence: A CDC Issue Brief for Researchers. Centers for Disease Control and Prevention. https:/www.cdc.gov/violenceprevention/pdf/Electronic_Ag gression Researcher Brief-a.pdf. Accessed December 28, 2018.

[2] Li, Q. New bottle but old wine: A research of cyberbullying in schools. Computers in human behavior,2007; 23(4), 1777-1791.

[3] Patchin, J. W., \& Hinduja, S. Bullies move beyond the schoolyard: A preliminary look at cyberbullying. Youth violence and juvenile justice, 2006; 4(2), 148-169.

[4] Smith, P. K., Mahdavi, J., Carvalho, M., Fisher, S., Russell, S., and Tippett, N. (2008). Cyberbullying: Its nature and impact in secondary school pupils. Journal of Child Psychology and Psychiatry, 49 (4), 376-385.

[5] Paulson, A. Internet bullying. http://www.csmonitor.com/2 003/1230/p11s01-legn.htm Accessed December 01, 2018.

[6] Hinduja, S. \& Patchin, J. W. Cyberbullying Identification, Prevention, and Response. https://cyberbullying.org/Cyberb ullying-Identification-Prevention-Response.pdf Accessed December, 25, 2018.

[7] Perry, M. Emotional and Social Effects of Cyberbullying on Adolescents (Doctoral dissertation, City University of Seattle).

https://repository.cityu.edu/bitstream/handle/20.500.11803/ 62/MichaelPerryThesis2015.pdf? sequence $=2 \&$ isAllowed $=$ y. Accesed December 26, 2018.

[8] Sleglova, V., \& Cerna, A. Cyberbullying in Adolescent Victims: Perception and Coping. Cyberpsychology: Journal of Psychosocial Research on Cyberspace, 2011; 5(2).

[9] Sourander, A., Klomek, A. B., Ikonen, M., Lindroos, J., Luntamo, T., Koskelainen, M., Henenius, H. Psychosocial risk factors associated with cyberbullying among adolescents. Archives of General Psychiatry, 2010; 67, 720728. doi:10.1001/archgenpsychiatry.2010.79

[10] Akbiyık, C., \& Kestel, M. An Investigation of Effects of Cyber Bullying on Students' Academic, Social and Emotional States. Mersin University Journal of the Faculty of Education, 2016; 12(3), 844-859. DOI: $10.17860 /$ mersinefd. 282384

[11] Yaman, E, Peker, A. The Perceptions of Adolescents about Cyberbullying and Cybervictimization. Gaziantep University Journal of Social Sciences, 2012; 11 (3), 819-833. Retrieved http://dergipark.gov.tr/jss/issue/24238/256940

[12] Mishna, F., Saini, M., \& Solomon, S. Ongoing and online: Children and youth's perceptions of cyber bullying. Children and Youth Services Review, 2009; 31(12), 1222-1228.

[13] Mark, L. and Ratliffe, K.T. Cyber Worlds: New playgrounds for bullying. Computers in the Schools, 2011; 28, 92-116.

[14] Erdur-Baker, Ö. ve Kavşut, F. Cyber Bullying: A New Face of Peer Bullying. Eurasian Journal of Educational Research, $2007 ; 27,31-42$.
[15] Erdur-Baker, Ö. Cyberbullying and its correlation to traditional bullying, gender and frequent and risky usage of internet-mediated communication tools. New Media \& Society, 2010; 12(1), 109-125. https://doi.org/10.1177/146 1444809341260

[16] Türküm, A. S., Balkaya, A. ve Karaca, A. The Adaptation of the Irrational Beliefs Scale to High School Students: Validity and Reliability Studies. Turkish Psychological Counseling and Guidance Journal, 2005; 3 (23), 77-85. Retrieved from http://dergipark.gov.tr/tpdrd/issue/21444/22 9615

[17] Liebenberg, L. Ungar, M. ve LeBlanc, J. C. The CYRM-12: A brief measure of resilience. Canadian Journal of Public Health, 2013; 104(2), 131-135.

[18] Arslan, G. Psychometric Properties of Child and Youth Resilience Measure (CYRM-12): The Study of Reliability and Validity. Ege Journal of Education, 2015; (16) 1: 1-1. DOI: $10.12984 /$ eed.23397

[19] Heckert, T.M., Cuneio, G., Hannah, A:P., Adams, P.J., Droste, H.E., Mueller, M.A. ve diğerleri.. Creatıon of a new needs assessment questionnaire. Journal of Social Behavior \& Personality,2000; 15(1), 121-136.

[20] Kesici, Ş. Yeni Psikolojik İhtiyaç Değerlendirme ölçeğinin Türkçe formunun geçerlilik ve güvenirlilik çalışması: Doğrulayıcı Faktör Analizi sonuçları. Selçuk Üniversitesi Sosyal Bilimler Enstitüsü Dergisi, 2008; (20), 493-500. file:///C:/Users/pc/Downloads/381-764-1-SM.PDF. Accessed December 28, 2018.

[21] Erbiçer, S. E. Examination of cyber bullying and cyber victimization among university students according to social adjustment and certain personal variables. (Master dissertation, Yıldiz Tecnichal University, İstanbul.) Retrieved from file://C:/Users/pc/Downloads/481949.pdf. 2017.

[22] Evegü, E. An analysis of adolescent cyberbullying in terms of shyness and some demographic variables. (Master dissertation, İnönü University, Malatya.) Retrieved from file:///C:/Users/pc/Downloads/384758.pdf. 2014.

[23] Pelfrey Jr, W. V., \& Weber, N. L. Keyboard gangsters: Analysis of incidence and correlates of cyberbullying in a large urban student population. Deviant Behavior, 2013; 34(1), 68-84.

[24] Wong, D. S., Chan, H. C. O., \& Cheng, C. H. Cyberbullying perpetration and victimization among adolescents in Hong Kong. Children and youth services review, 2014; 36, 133-140.

[25] Bayhan, V. Lise öğrencilerinde internet kullanma alışkanlığı ve internet bağımlılığı (Malatya Uygulamas1). Young, 1998; $237,244$.

[26] Kelleci, M., Güler, N., Sezer, H. \& Gölbaş, Z. Relationships Gender and Psychiatric Symptoms with Duration of Internet Use among High School Students, TAF Prev Med Bull 2009; $8(3): 223-230$

[27] Russell, A., Aloa, V., Feder, T., Glover, A., Miller, H., \& Palmer, G. Sex-based differences in parenting styles in a sample with preschool children. Australian Journal of Psychology, 1998; 50(2), 89-99. 
[28] Baykal, F. Relationship between cyberbullying/ cybervictimization and family protective factors in high schools: Afyonkarahisar province case.(Master dissertation, Afyon Kocatepe University, Afyon.) Retrieved from file://C:/Users/pc/Downloads/447709.pdf. 2016.

[29] Makri-Botsari, Evi, Georgia Karagianni. Cyberbullying İn Greek Adolescents: The Role of Parents. Procedia-Social And Behavioral Sciences. 2014; 16: 3241- 3253

[30] Kavuk, M. ve Keser, H. İlköğretim okullarında siber zorbalık. Hacettepe Üniversitesi Eğitim Fakültesi Dergisi [Hacettepe University Journal of Education], 2016; 1-16. Doi:10.16986/HUJE.2015014222.

[31] Juvonen, J. and Gross, E. F. Extending the school grounds? bullying experiences in cyberspace. Journal of School Health, 2008; 78 (9), 496-505.

[32] Göldağ, B. An Investigation of the Relationship Between Internet Addiction Levels and Trait Anxiety Levels of Students in Secondary Education Institutions. Turkish Studies, 2017; 12(11), 71-94. DOI: 10.7827/TurkishStudies .11862

[33] Özdemir, M. ve Akar, F. Examination of High School Students' Opinions on Cyberbullying in Terms of Various Variables. Kuram ve Uygulamada Eğitim Yönetimi [Educational Administration: Theory and Practice], 2011; 17(4), 605-626.

[34] Semerci, A. Examination of High School Students' Cyberbullying and Victimization Cases in Terms of Different Variables. Kastamonu Education Journal, 2017;
25(4), 1285-1300.

[35] Birle, D., \& Boșca, S. The Relatıonshıp Between Bullyıng And Irratıonal Beliefs In A Sample Of Romanian Students. Romanian Journal of School Psychology, 2013; 6(11), 126-133.

[36] Fives, C. J., Kong, G., Fuller, J. R., \& DiGiuseppe, R. Anger, aggression, and irrational beliefs in adolescents. Cognitive therapy and research, 2011; 35(3), 199-208.

[37] Kabadayi, F., \& Sari, S. V. What is the Role of Resilience in Predicting Cyber Bullying Perpetrators and Their Victims? Journal of Psychologists and Counsellors in Schools, 2018; 28(1), 102-117.

[38] Hinduja S, Patchin J. W. Cultivating youth resilience to prevent bullying and cyberbullying victimization. Child Abuse Neg. 2017; 173:51-62

[39] Navarro, R., Yubero, S., \& Larrañaga, E. Cyberbullying victimization and fatalism in adolescence: Resilience as a moderator. Children and Youth Services Review, 2018; 84, 215-221.

[40] Dilmaç, B. Psychological Needs as a Predictor of Cyber bullying: a Preliminary Report on College Students. Educational sciences: Theory \& Practice, 2009; 9 (3), 1291-1325.

[41] Eşici, H. The relationship between bullying behaviours and fulfilling basic needs based on choice theory. The Journal of Turkish Educational Sciences, 2013; 11 (2), 151-168. Retrieved fromhttp://dergipark.gov.tr/tebd/issue/26092/274 943 